\title{
Analisis Distribusi Frekuensi-Magnitudo Gempabumi Di Wilayah Sulawesi Utara
}

\author{
Sarah Selviana Homer1)*, Guntur Pasau1), Ferdy1) \\ 1)Jurusan Fisika, FMIPA, Unsrat, Manado
}

K A T A K U N C I

Seismisitas

Perulangan gempabumi

Maximum likelihood

\begin{tabular}{l}
\hline K E Y W O R D S \\
\hline Stone fragility \\
Seismicity \\
Reccurence earthquake \\
Maximum likelihood
\end{tabular}

AVAILABLE ONLINE

08 November 2013

\begin{abstract}
A B S T R A K
Analisis Distribusi Frekuensi-Magnitudo Gempa Bumi di Wilayah Sulawesi Utara telah dilakukan. Analisis Distribusi Frekuensi-Magnitudo Gempa Bumi menggunakan metode maximum likelihood merupakan upaya mitigasi dalam menentukan nilai parameter gempa (nilai $a-b$ ), perulangan gempa merusak, serta daerah berpotensi gempa merusak.

Hasil data ANSS menunjukan bahwa pada timur (dalam arah utaraselatan) mempunyai nilai $a-b$ yang lebih rendah dibandingkan barat wilayah SULUT, dengan nilai masing-masing sekitar 7-7,8 dan 0,8-1,5. Hasil perhitungan perulangan gempa merusak (Magnitudo $M w=7$ ) sekitar 15-20 tahun. Daerah berpotensi gempa merusak adalah : Kabupaten Kepulauan Sangihe, Kabupaten Kepulauan Sitaro, kota Bitung (terutama kecamatan Lembah Utara dan Selatan).
\end{abstract}

A B S T R A C T
Analysis of Frequency-Magnitude Distribution of earthquakes in North
Sulawesi region has been performed. Analysis of Frequency-Magnitude
Distribution of earthquakes using the maximum likelihood method in
determining the value of mitigating earthquake parameters (values a -b),
recurrence earthquake damage, as well as the potential area of
earthquake damage.
Data of ANSS is showed that in east (in the direction north-south) has
lower than of a-b that that in the western area of North Sulawesi, with
each value of around 7 to 7.8 and from 0.8 to 1.5 . Calculation of
recurrence earthquake damage (Magnitude Mw $=7$ ) resulted in a period
of $15-20$ years old. Areas with potential earhquake damage are: District
Sangihe Islands, Islands District Sitaro, Bitung city (especially north and
south valley districts).

\section{Pendahuluan \\ Gempabumi tektonik merupakan salah satu bencana alam yang sangat ditakuti oleh umat manusia, karena menyebabkan kerugian yang besar, apalagi gempa yang terjadi dengan kekuatan (magnitudo) yang tinggi. Bencana ini tidak dapat ditentukan dengan pasti kapan dan bagaimana kejadiannya, namun dapat dilakukan pendekatan mengenai prediksi kejadian gempa tersebut, yaitu dengan berbagai \\ Metode dengan sejumlah peralatan pendeteksi gempa yang semakin canggih di masa kini.}

Gempa tektonik biasanya terjadi di daerahdaerah pertemuan antar lempeng yaitu pada daerah subduksi (penunjaman) dan sesar (patahan).

Wilayah Sulawesi Utara (SULUT) dan daerah sekitarnya terletak di antara batas-batas pertemuan lempeng tektonik (Gambar 1.).

*Corresponding author: Jurusan Fisika FMIPA UNSRAT, Jl. Kampus Unsrat, Manado, Indonesia 95115; Email address: sarahhomer@yahoo.com Published by FMIPA UNSRAT (2013) 


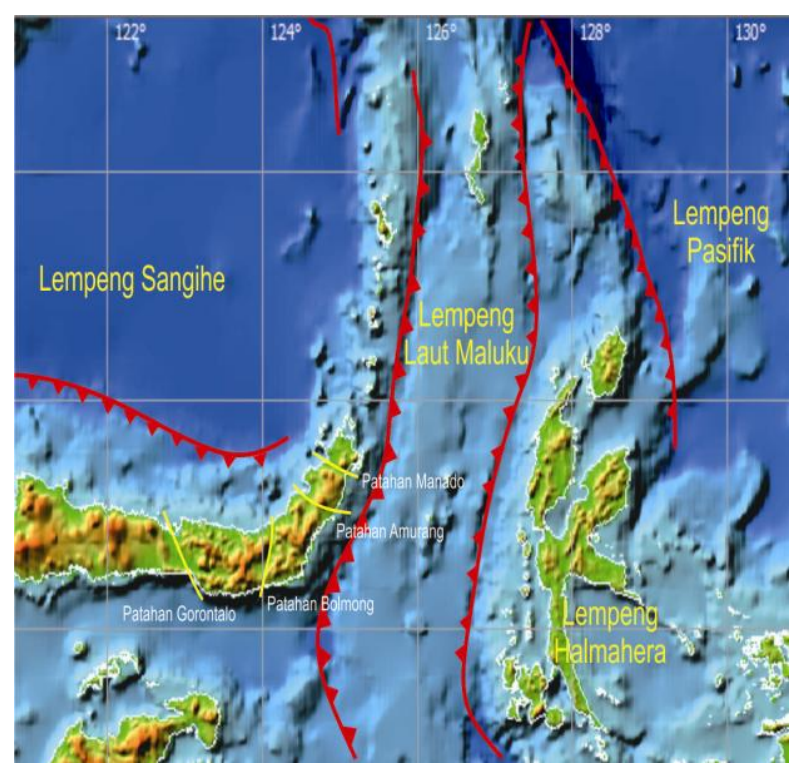

Gambar 1. Peta lempeng tektonik wilayah SULUT dan daerah sekitarnya

Pergerakan lempeng yang menyebabkan subduksi dan Sesar ini mengakibatkan Wilayah Sulawesi Utara merupakan salah satu wilayah di Indonesa dengan tingkat aktifitas seismik tinggi (Gambar 2.).

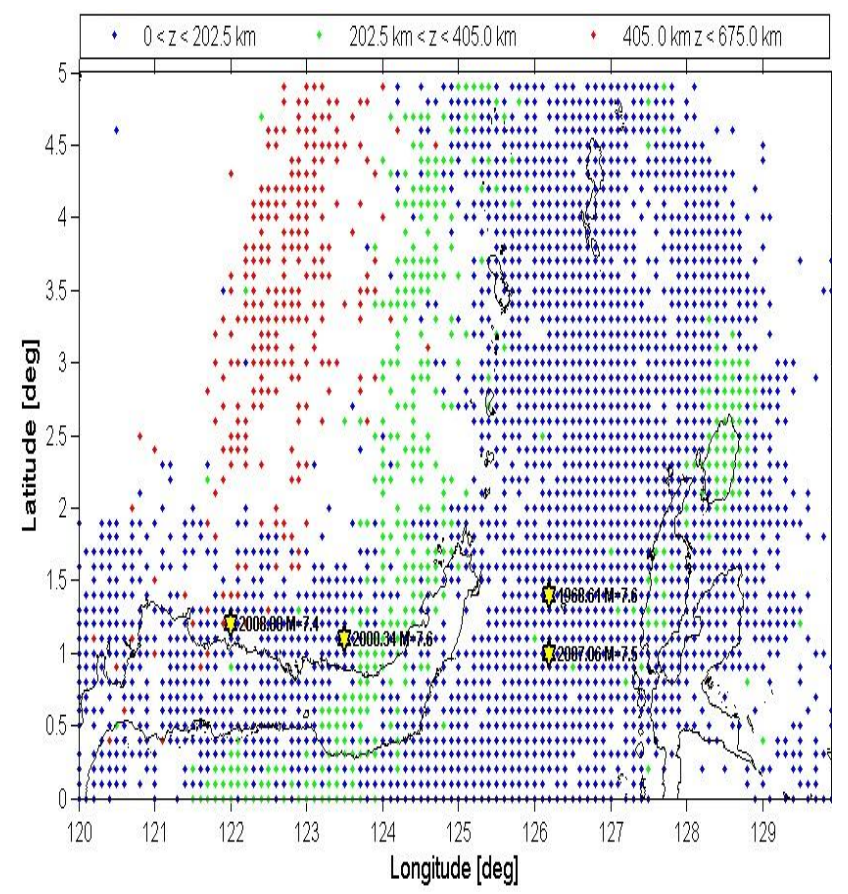

Gambar 2. Peta seismisitas Wilayah Sulawesi Utara dan sekitarnya (ANSS)

Selain pertemuan antar lempeng, tingkat kerapuhan batuan suatu wilayah (nilai- $b$ ) juga mempengaruhi tingkat aktifitas seismik (nilai- $a$ ) bahkan sangat mempengaruhi besarnya kekuatan gempa (magnitudo) gempabumi yang akan dilepaskan. pada wilayah tersebut.

Berdasarkan peneliti para ahli sebelumnya bahwa besarnya kekuatan (magnitudo) gempabumi yang terjadi berbanding terbalik dengan tingkat kerapuhan batuan (nilai- $b$ ) suatu wilayah. Wilayah aktifitas seismik (nilai- $a$ ) tinggi akan berkorelasi dengan kerapuhan batuan (nilai-b) tinggi pula, sedangkan pada wilyah ini kekuatan gempa (magnitudo) yang akan dilepaskan relatif kecil, dan sebaliknya.

Untuk meminimalisasi dampak bencana gempa bumi di wilayah SULUT, tentu upaya mitigasi perlu dilaksanakan secara dini dan optimal. Salah satu cara untuk meminimalisir dampak bencana gempa bumi sebagai upaya mitigasi, adalah dengan menghitung nilai kerapuhan batuan (nilai- $b$ ) serta nilai aktifitas seismik (nilai- $a$ ) berdasarkan peta persebaran Distribusi Frekwensi-Magnitudo (Frekquency-Magnitude Distribution, FMD), menggunakan salah satu metode statistik yaitu maximum likelihood, guna menentukan nilai estimasi parameter gempa (nilai $a-b$ ), dimana kedua nilai ini masing-masing menunjukan tingkat aktifitas seismik dan tingkat kerapuhan batuan pada wilayah penelitian.

Penentuan nilai $a-b$ dilakukan berdasarkan suatu formulasi persamaan yang diberikan oleh Utsu (1965). Penentuan nilai $a-b$ pada penelitian ini dilakukan berdasarkan metode maximum likelihood karena menurut Utsu (1961) metode ini lebih baik dan teliti dalam menganalisis Distribusi FrekuensiMagnitudo. Hal ini juga dijelaskan oleh Pasau dan Tanauma (2011) bahwa Estimasi parameter gempa menggunakan analisis statistik model maximum likelihood, memberikan hasil yang lebih stabil karena memodelkan kemiringan garis bukan dari hasil fitting least square tiap magnitudo, tapi kemiringan nilai tengah (mean) magnitudo fungsi distribusi Gaussian.

\section{Metode}

Secara garis besar langkah-langkah dalam penelitian ini adalah:

1. Studi Literatur

Studi literature adalah menelaah pustaka yang mendukung penelitian tentang Analisis Distribusi Frekuensi-Magnitudo Gempabumi di Wilayah SULUT.

2. Pengumpulan data gempa

Data gempa yang digunakan dalam penelitian ini adalah katalog ANSS (tahun 1963-2013) dan USGS (tahun 1963-2013)

3. Pengolahan data

a) Konversi skala magnitudo

Gempa yang direkam pada katalog data gempa biasanya menggunakan skala magnitudo yang berbeda-beda, untuk itu perlu diseragamkan skala mahnitudo 
tersebut menjadi moment magnitude $(M W)$, menggunakan bantuan Microsoft Excel

b) Penyortiran Katalog gempa

Proses penyortiran katalog gempa bertujuan untuk memilah gempa utama terhadap gempa-gempa rintisan dan susulan, sehingga didapat empa yang Independen menggunakan Software ZMAP

c) Penentuan nilai Magnitude of Completeness (Mc)

d) Perhitungan nilai parameter gempa (nilai $a-b)$ secara spasial

Dilakukan dengan membagi wilayah penelitian menjadi 4 wilayah, dan nilai $a-b$ dihitung pada masing-masing wilayah menggunakan software ZMAP

e) Perhitungan perulangan gempabumi merusak secara spasial perlakuannya dibuat setelah nilai $a-b$ diketahui, kemudian nilai perulangan gempa dihitung berdasarkan hasil pemetaan nilai $a-b$

4. Analisis Spasial

Analisis spatial dilakuan berdasarkan hasil perhitungan nilai $a-b$ serta perulangan gempa yang dilakukan secara spatial. Prediksi daerah berpotensi mengalami gempa bumi merusak diprediksi berdasarkan hasil analisis spatial.

\section{Hasil dan Pembahasan}

Berdasarkan data ANSS didapat nilai $a-b$ rendah yaitu pada timur wilayah SULUT dan sebaliknya nilai $a-b$ tinggi di sebelah barat. Begitupun halnya dengan perulangan gepabumi merusak relatif lebih cepat di timur wilayah SULUT di banding bagian barat wilayah ini.
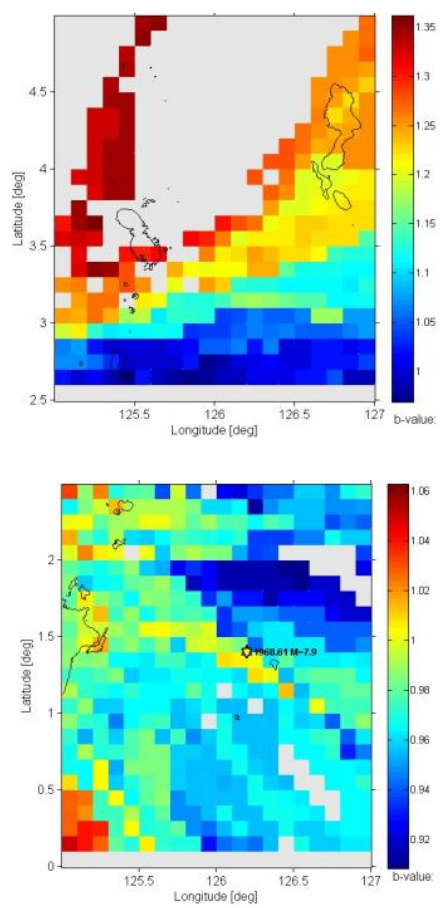

Gambar 3. Hasil nilai-b untuk wilayah Timur SULUT (data ANSS)
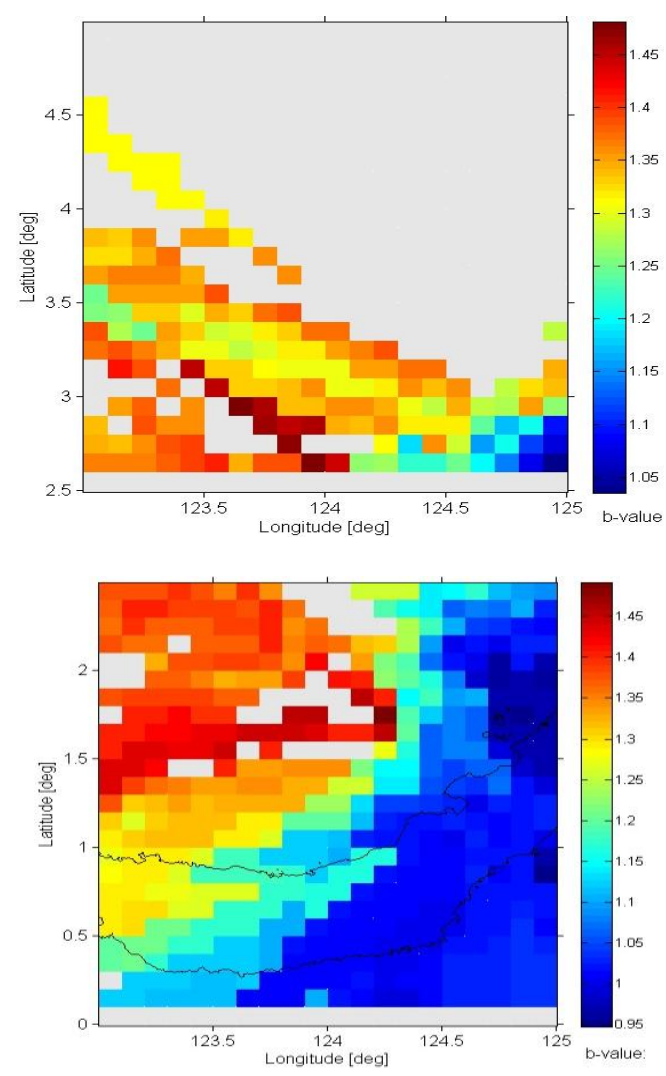

Gambar 4. Hasil nilai-b untuk wilayah Barat SULUT (data ANSS)

\section{Kesimpulan}

Menurut hasil data ANSS dan USGS menunjukan bahwa pada timur (dalam arah utaraselatan) mempunyai nila $a-b$ yang lebih rendah dibandingkan barat wilayah SULUT, yaitu sekitar 77,8 untuk nilai- $a$ dan 0,8-1,5 untuk nilai- $b$. Perkiraan perulangan gempabumi merusak (Magnotudo $M w=7$ ) adalah 15-20 tahun.

\section{Daftar Pustaka}

Afnimar, 2009. Seismologi. ITB, Bandung.

Bufe, C.G. 1970, Frequency-Magnitude Variations During the 1970 Danville earthquake Swarm, Earthquake Notes, 41: 3-6.

EPRI (Electric Power Research Institute). 1994. Fourth International Conference on Cold Fusion Volume 1: Plenary Session Papers, TR-104188V1. Lahaina, Maui, Hawai.

Gibowicz, S.J. 1997, Variation of the frequencymagnitude relation during earthquake sequences in New Zealand.Bull. Seismol. Soc. Am. 63:517528.

Hall, R. dan Wilson, M.E.J. 2000. Neogene Sutures in Eastern Indonesia, Journal of Asian Earth Sciences, 18:781-808. 
Ibrahim, G., dan Subarjo. 2005. Pengetahuan Seismologi. Badan Meteorologi dan Geofisika,Jakarta.

Kertapati, E. 2006. Aktifitas Gempa Bumi di Indonesia, Persfektif Regional pada Karekteristik Gempa Bumi Merusak. Badan Geologi, Bandung.

Munadi, Suprajitno. 2000. Aspek Fisis Seismologi Eksplorasi. Universitas Indonesia, Depok.

Pasau, G., dan A. Tanauma. 2011. Pemodelan Sumber Gempa di Wilayah Sulawesi Utara Sebagai Upaya Mitigasi Bencana Gempa Bumi. Journal science of MIPA. 7:1-5.

Scordilis, E.M. (2006) : Empirical Global Relations Converting $\mathrm{MS}$ and $\mathrm{Mb}$ to Moment Magnitude, Journal of Seismology, 10: 225-236.

Simandjuntak, T.O. 1992. An Outline of Tectonics of the Indonesian Region. Geological News Letter,
252(3): 4-6. Geological and DevelopmentCenter, Bandung-Indonesia.

Supriyanto, R. 2009. Studi Seismotektonik Sebagai Indikator Potensi Gempa Bumi di Wiayah Indonesia. Jurnal Meteorologi dan Geofisika, 10(2): 111-120

Utsu, T. (1965), A Method in Determining the value of $b$ in a formula $\log N=a-b M$ Showing the magnitude frequency for earthquakes. Geophys Bull. Hokkaido Univ. 13 : 99-103

Wandono et al. 2004. Analisis Hubungan FrekwensiMagnitudo Gempa Bumi di Bali dan Sekitarnya. Jurnal Matematika dan Sains. 9(3): 273-277

Widiyantoro, S. (2007) : Fisika dan Struktur Intrior Bumi, Penerbit Badan Meteorologi dan Geofisika Jakarta, ISBN 978-979-1241-06-09. 